\title{
Performance analysis of cocoa certification program in Polewali Mandar Regency
}

\author{
Fitriani Herman ${ }^{*}$, Muhammad Arsyad ${ }^{2}$, Ikawati Karim ${ }^{3}$, and Nurlaela ${ }^{4}$ \\ 1,3,4Agribusiness Department, Universitas Sulawesi Barat, Indonesia \\ ${ }^{2}$ Socio-economic of Agriculture Department, Universitas Hasanuddin, Indonesia \\ *Corresponding author's e-mail: fitrianiherman1994@gmail.com
}

Received November 29th, 2019; revised December 29th, 2019; accepted January 6th, 2020

\begin{abstract}
One of the agricultural development incomes is through agribusiness activities oriented to increasing competitiveness and sustainable economic development of the community, which is carried out within the framework of autonomy to strengthen the regional economy. Cocoa is a strategic commodity in case, firstly, Indonesia is the number two cocoa producer in the world after Ivory Coast, with production of 809,586 tons in 2012. In 2012, this commodity has contributed foreign exchange of US \$ 1.1 billion, which is the third foreign exchange earnings spread after oil palm and rubber. Secondly, this product involves $95 \%$ of smallholder farmers with increased land ownership of 0.5-2 ha. Thus, the development of the cocoa business will directly or indirectly affect the microeconomics. This study aims to determine the performance and the level of satisfaction of the cocoa certification program in one of cocoa production center in Polewali Mandar. This study uses Importance Performance Analysis (IPA). The results of this study indicate that the achievement of the performance of the cocoa certification program has been running quite well, but there are still some that have not worked optimally where the level of satisfaction of the cocoa certification program that $78.03 \%$ are satisfied with the program's performance cocoa certification and $21.97 \%$ farmers were not satisfied with the performance of the cocoa certification program carried out in Polewali Mandar.
\end{abstract}

Keywords:

Cocoa, Certification, Performance, Polewali mandar

\section{Introduction}

One of the strategic agricultural products is the cocoa (Theobrema cacao L.). Cocoa is a strategic commodity at least for two reasons. First, Indonesia is the number two cocoa producer in the world after Ivory Coast, with production of 809,586 tons in 2012 [1]. With such production, this commodity has contributed foreign exchange of US \$ 1.1 billion in 2012, which is the third foreign exchange earnings spread after oil palm and rubber. Second, this business activity involves $95 \%$ of smallholder farmers with increased land ownership of 0.5-2 ha. Thus, the development of the cocoa farming will directly or indirectly affect the people's economy. Of the total Indonesian cocoa production, the largest contribution (60\%) came from four provinces in Sulawesi, namely South Sulawesi, West Sulawesi, Southeast Sulawesi, and Central Sulawesi.

As a source of livelihood for most of the farmers in Polewali Mandar Regency, cocoa farming can support economic life in the area. In fact, the cocoa farming has not yet provided optimal benefits for cocoa farmers. Some of the causes are lack of optimal productivity, farmers' weak bargaining position in the trade value chain and several other factors. This is because, farmers do not have a strong bargaining position in the cocoa trade chain. This low bargaining position is due to several factors such as 
the majority of farmers' cocoa being bought by collectors, farmers' productivity is low and cocoa trading chains are still inefficient.

In the study area, cocoa is certified by partners to maintain the quality of cocoa beans in the on-farm sub system. Cocoa certification can increase farmers' income and farmers' performance as well, it is because with the cocoa certification, the quality of cocoa bean would be guaranteed by the government so that the price of cocoa bean is higher than unguaranteed cocoa bean.

Sulawesi is the largest cocoa producer in Indonesia, and especially in the area of West Sulawesi, there are several areas that have cocoa plant areas such as Mamuju, Majene and Polewali Polewali Mandar Regencies. In Polewali Mandar, there are several areas where the main commodity is cocoa, one of them is in Tapango District. In this district, most of farmers collaborate with private sector to certify of cocoa bean in order to get high price standard. Tapango District is an area that has a large area of land for cocoa commodity, reaching 49. 167, 77 hectares with cocoa production reaching 31,969, 46 tons. In Tapango District, there are 14 villages and cocoa plants are the mainstay commodity and as the main livelihood in every village in Tapango District. Moreover, the other commodities are coffee and coconut [2]. Bussu Village as the study area is a village included in Tapango District, whose main livelihood is cocoa farming, this can be seen with the area of cocoa in the village reaching 449.00 hectares of cocoa plantation. The village has an advanced cocoa farmer group, this can be showed from the farmer groups in the village who are already certified.

The institutions that certify the cocoa certification program in Tapango District, Polewali Mandar Regency, are the UTZ (Armajaro) and Rainforest Alliance (RA) Institutions.

The objectives of cocoa certification are:

a. Maintenance and optimization of soil fertility and soil structure.

b. Plant protection.

c. Agro-chemical storage.

d. The steps include harvesting and post-harvesting.

e. Instructions for use of pesticides.

f. List of recommended plant protection products with application instructions.

g. The Integrated Management/Integrated Pest Management (ICM/IPM) method that will be used.

h. Work health and safety for workers/farmers

i. Labor rights.

j. Conservation and environmental protection.

Based on this background and problems, this study aims to analyze the performance of the cocoa certification and the level of satisfaction of the cocoa certification in Tapango District, Polewali Mandar Regency.

\section{Method}

This research was conducted in Bussu Village, Tapango District, Polewali Mandar Regency where data collection began from January to May 2018. To answer the objectives to be achieved in this study used the method of Importance Performance Analysis (IPA) whuch is used to find out: 1) analysis of the performance of cocoa 
certification program and 2) level of satisfaction of the cocoa certification program. This tool is used to measure a person's level of satisfaction over the performance of other parties. In many times, Importance Performance Analysis (IPA) is used to measure satisfaction with performance or programs that are carried out by others or by institutions. In this research, farmers provide an assessment of the performance and satisfaction received from the certification program. If the level of expectation is higher than the performance of the government through the certification program, it means that the farmer has not yet reached satisfaction.

To find out the level of satisfaction of the farmers is analyzed between the interests and the real service represented by the $Y$ and $X$ symbol, where $X$ is the level of performance that gives, while $\mathrm{Y}$ is the importance, the formula used is:

$$
\mathrm{TKi}=\mathrm{X}_{1} \mathrm{Y}_{1} \times 100 \%
$$

Where:

$$
\begin{aligned}
& \mathrm{TKi}=\text { The level of suitability of the respondent } \\
& \mathrm{X}_{1}=\text { Farmers performance evaluation score } \\
& Y_{1}=\text { Scores on farmers' interests }
\end{aligned}
$$

The horizontal axis $(X)$ will be filled by the performance level score while the vertical axis $(Y)$ will be filled by the importance level score. In the distribution of the formula, for each attribute that affects farmer satisfaction can be determined by the formula:

$$
\mathrm{X}=\mathrm{X}_{1} \mathrm{n} \quad \mathrm{Y}=\mathrm{Y}_{1} \mathrm{n}
$$

Cartesian diagram is used to find out which service indicators are satisfactory or unsatisfactory for farmers. The formula used is:

$$
X=I=1 N X K \quad Y=i=1 N Y K
$$

\begin{tabular}{|c|c|c|}
\hline$\underline{Y}$ High & $\begin{array}{c}\text { A } \\
\text { Major priority }\end{array}$ & $\begin{array}{l}\text { B } \\
\text { Achievement Priority }\end{array}$ \\
\hline & $\begin{array}{c}\text { C } \\
\text { Low Priority }\end{array}$ & $\begin{array}{c}\text { D } \\
\text { Over Priority }\end{array}$ \\
\hline
\end{tabular}

Where:

$\mathrm{K}=$ many farmers influence work satisfaction

Farmers' expectation

Figure 1. Cartesian diagram

A. Indicates factors or attributes that are considered to influence farmer satisfaction. Including service elements that are considered very important, but 
management has not carried out in accordance with the wishes of farmers so that it is dissatisfied.

B. Indicates the basic service elements that have been successfully carried out. For this reason, it must be maintained. Considered very important and very satisfying.

C. Indicates some factors that are less important influence on farmers. Implementation by farmers is not important. Considered less important and less satisfying.

D. Indicates the factors that influence farmers are less important, but the implementation is excessive. Considered less important but very satisfying [3].

\section{Results and Discussion}

\subsection{Importance Performance Analysis (IPA)}

The results of the IPA analysis to find out the level of satisfaction of farmers analysed between the interests and real services represented by the letters $X$ and $Y$, where $X$ is the level of performance of the certification program that gives while $Y$ is the level of farmer satisfaction with the performance provided by the certification. The analysis used is the IPA analysis. The analysis of the results of research conducted by the author shows that the program is very important for farmers for cocoa farming activities.

$\mathrm{TKi}=\mathrm{X} 1 \mathrm{Y} 1 \times 100 \%$

$\mathrm{TKi}=47.101 \times 100 \%=46.54$

Calculate the level of total agreement (TKi Total) between the values of $X$ (satisfaction level) with the value of $Y$ (how important).

$\sum X \mathrm{X}=1694$

$\sum Y i=2171$

TKi total $=\sum \mathrm{xi} \sum \mathrm{yi} \times 100 \%$

$$
=16942171 \times 100 \%=78.03 \%
$$

Average score for satisfaction $(X)$ and importance $(Y)$

$\mathrm{X}=\mathrm{i}=1 \mathrm{NXK}$

$X=80.6723$

$X=3.51$

So, the average satisfaction score $(X)$ is 3.51

$\mathrm{Y}=\mathrm{i}=1 \mathrm{NYK}$

$Y=103.3823$

$\mathrm{Y}=4.49$

So, the average score of importance $(\mathrm{Y})$ is 4.49 
Farmers' expectation

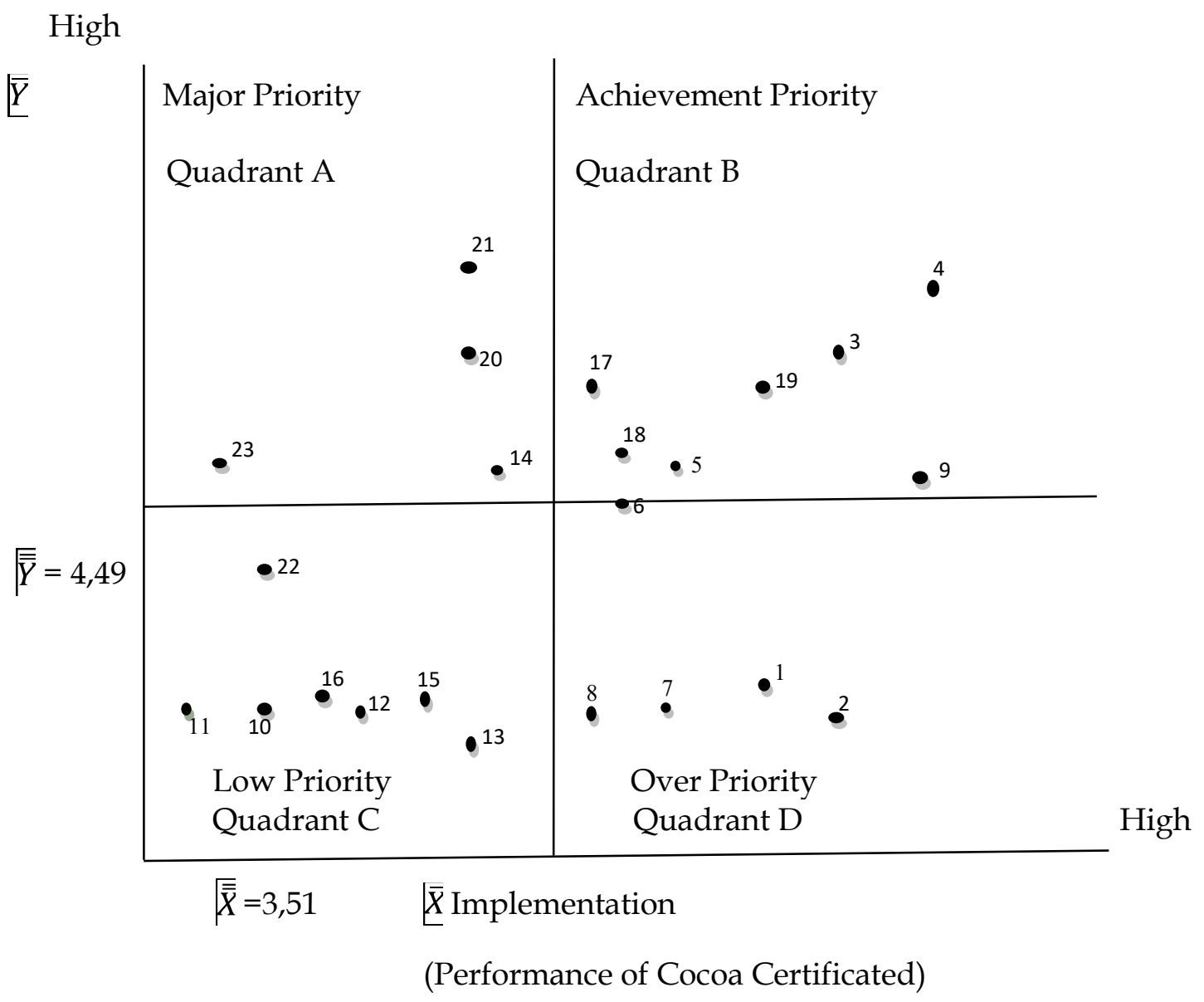

Figure 2. Cartesian diagram of cocoa certification program

Based on the Natural Sciences Graph in Figure 1, the factors related to the cocoa certification program in Bussu Village, Tapango District, Polewali Mandar District, can be grouped in each quadrant as follows:

a. Indicates factors or attributes that are considered to influence farmer satisfaction. Including service elements that are considered very important, but the management has not implemented it in accordance with the wishes of farmers, so they are not satisfied. The attributes in quadratic A based on the priority order of improvement are (14) safety standards in the use and mixture of pesticides, (20) provide an understanding of how to control fruit rot, (12) Provide an understanding of how to control VSP, Anthracnose and mushrooms, (23) clothing standards suggested by the certification.

b. Shows the basic service elements that have been successfully carried out. For this reason, it must be maintained. Considered very important and very satisfying. As for the attributes in quadrant B based on the order of priority, the repairs are (3) training/information related to the maintenance of cocoa plants, (4) information or training related to proper fertilization methods, (5) information about cocoa plant pest control standards, (6) Information on procedures for harvesting and post-harvesting according to standards, (9) 
Provision of cocoa beans drying and drying, (17) Provision of appropriate protective equipment, (18) Introduction and training of methods and methods of pest control, (19) Provision of adequate sanitation good.

c. Shows some factors that are less important influence on farmers. Considered less important and less satisfying. As for the attributes in square $C$ based on priority order are (10) the availability of fermented cocoa beans, (11) Utilization of cocoa bean drying machine technology, (12) the availability of fruit sorting/separator tools, (13) training related to the use of tools, (15) Provision of locations/pesticide disposal sites, (16) Introduction of training related to the application of pesticides in the field, (22) Foods recommended by the certification.

d. Shows the factors that influence farmers are less important, but the implementation is excessive. Considered less important but very satisfying. The attributes in quadrate $\mathrm{D}$ based on the order of priority for improvement are (1) Control of how to prepare land properly, (2) Provision of cocoa seedlings and nursery locations, (7) Preparation of cocoa beans warehouse/storage, (8) Information on how to harvest right.

\section{Conclusion}

Based on the results and discussion, this research can be concluded that the achievement of the performance of the cocoa certification program in Polewali Mandar has been running in accordance with the work program being carried out. However, there are still some that have not been implemented well and the level of satisfaction of the cocoa certification program in Bussu Village shows that $78.03 \%$ of respondents were satisfied with the performance of the cocoa certification program and $21.97 \%$ of respondents were not satisfied with the performance of the cocoa certification program conducted in Bussu Village.

\section{References}

1. Pangan jajanan yang sehat. Direktorat Perlindungan Konsumen, Depatemen Perdagangan RI. Jakarta; 2006.

2. BPP Kecamatan Tapango; 2016.

3. Supranto J. Pengukuran tingkat kepuasan pelanggan: untuk menaikkan pangsa pasar. Jakarta: Rineka Cipta; 2006. 300 p. 